\title{
Ovit Yaylasının (İkizdere-RİZE) Botanik Kompozisyonunun Belirlenmesi
}

\author{
Muhammed İkbal ÇATAL $^{1^{*}}$ Hüseyin BAYKAL ${ }^{2} \quad$ Adil BAKOĞLU $^{2}$ \\ ${ }^{1 *}$ Recep Tayyip Erdoğan Üniversitesi, Ziraat ve Doğa Bilimleri Fakültesi, Tarla Bitkileri Bölümü, Rize, Türkiye. \\ ${ }^{2}$ Recep Tayyip Erdoğan Üniversitesi, Pazar Meslek Yüksek Okulu, Bitkisel ve Hayvansal Üretim Bölümü, Rize, Türkiye.

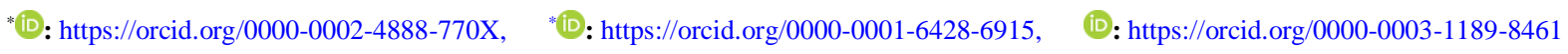

Öz: Bu çalışma Rize ili İkizdere ilçesine bağlı Ovit yaylasında 2019 yılında, Lup metoduyla yapılmıştır. Çalışmada toprağı kaplama ve botanik kompozisyon oranları ve mera durum sınıfı incelenmiştir. Çalışmada buğdaygillere ait 6 , baklagillere ait 4 ve diğer familyalara ait 35 olmak üzere toplam 45 takson tespit edilmiştir. Çalışma alanının toprağı kaplama oranı \%63,40, botanik kompozisyonda buğdaygillerin oranı $\% 39,35$, baklagillerin oranı $\% 6,61$ ve diğer familyaların oranı da \%54,04 olarak tespit edilmiştir. Merada en yaygın bulunan ilk üç takson sırasıla; Festuca woronowii subsp. turcica $(\% 17,66)$, Nardus stricta $(\% 13,90)$ ve Sibbaldia parviflora var. parviflora $(\% 12,80)$ olmuştur. Meranın durumu 1,976'lik mera derecesi ile çok zayıf olarak belirlenmiştir. Başta kontrollü otlatma ve üstten tohumlama olmak üzere diğer ıslah yöntemlerinin birlikte uygulanması sonucuna varılmıştır.

Anahtar sözcükler: Botanik kompozisyon, mera durumu, Ovit yaylası, toprağı kaplama oranı.

\section{A Determination on The Botanical Composition of Ovit Plateau (Ikizdere-RİZE)}

\begin{abstract}
In this study conducted in Ovit plateau of Ikizdere district of Rize province in 2019, Lup method was used. In this study, canopy cover and botanical composition ratios and pasture condition class were examined. As a result of the study a total of 45 taxa; 6 belonging to Poaceae, 4 belonging to Fabaceae and 35 belonging to other families were identified. The rate canopy covering of the research area was $63.40 \%$, the rate of Poaceae in the botanical composition was $39.35 \%$, the rate of the Fabaceae $6.61 \%$ and the ratio of the other families $54.04 \%$. The first three taxa, the most common found in pasture, respectively; Festuca woronowii subsp. turcica (17.66\%), Nardus stricta (13.90\%) and Sibbaldia parviflora var. parviflora (12.80\%). The pasture condition was found to be very weak with 1.976 pasture degree. It was concluded that especially controlled grazing and top-seeding, were applied together other methods of breeding.
\end{abstract}




\section{GİRIŞ}

Çayır ve meralar, hayvanların beslenmesinde ihtiyaç duyulan en önemli yem kaynaklardır (Aydın \& Uzun, 2002). Bunun dışında çayır meraların kültür bitkileri için gen kaynağı olması, biyolojik çeşitlilik oluşturması ve erozyona karş1 toprağ1 korumas1 gibi birçok önemli yarar1 da bulunmaktadır (Carlier vd., 2005). Hayvanların ihtiyaç duydukların kaba yemin \%30'u çayır ve meralardan sağlanmaktadır (Gökkuş, 1994). Ülkemiz hayvan varlığının bir yılda tükettiği besinlerin ham protein olarak $\% 68$ 'i, nişastanın da \%62'si karşılamaktadır (Okatan \& Yüksek, 1997; Babalık \& Sarıkaya, 2015).

Ülkemiz meralarında yıllardan beri devam eden aşırı ve erken otlatma ile ıslah ve bakım işlemlerinin yapılmaması nedeniyle meraların bitki örtüsü büyük oranda bozulmuş ve ot verimleri azalmıştır (Yavuz \& Sürmen, 2016; Sürmen \& Kara, 2018). Bu sorunun çözülebilmesi için ot verimi ve kalitesi düşmüş olan meraların ıslah edilerek yeniden yüksek verime sahip kaliteli yem üretir duruma getirilmeleri gerekir. Ancak, mera sslahında başarılı olabilmek için, öncelikle ıslah edilecek meranın vejetasyon yapısının iyi bilinmesi önemlidir (Çınar vd., 2019). Meranın vejetasyon yapısını tespit etmek için öncelikle o yöreye ait botanik ve floristik kompozisyon çalışmaları yapılmalıdır.

1940 'lı yıllarda yaklaşık 45 milyon olan mera alanı varlığımız sürekli azalma göstermiş ve günümüzde 14,6 milyon hektara kadar düşmüştür (TÜiK, 2019). Rize ilinde ise toplam 45,332 ha çayır-mera alanı bulunmaktadır (Anonim, 2018).

Ülkemizde son yıllarda yapılan botanik kompozisyonla ilgili çalışmalara baktığımızda; Babalık ve Sarıkaya, (2015) tarafindan yapılan çalışma da familyaların bitki ile kaplı alan ve botanik kompozisyon oranları sırasıyla buğdaygiller \%13,90-65,31, baklagiller \%3,50-16,39 ve diğer familya bitkileri \%4,35-20,10 olduğu; Gür ve Altın, (2015) farklı mera uygulamalarında yaptı̆ğ çalı̧̧mada, bitki ile kaplı alan oranlar1 otlatılan merada $\% 79,06$, korunan merada \% 84,48 ve sürülüp terk edilen merada $\% 65,85$ oranında belirlediğini ve toplamda 206 farklı takson tespit ettiğini; Bilgin ve Özalp, (2016) tarafından yapılan çalışma da botanik kompozisyonun \%46,19 ile buğdaygillerden, \%14,36 ile baklagillerden ve \%39,45 ile diğer familyalardan oluştuğu; İspirli vd., (2016) Kastamonu ili, Taşköprü ilçesine bağlı 12 köyün doğal meralarında yapılan çalş̧malarda bitkiyle kaplı alan oranı ortalamas $\%$ 83,34, meraların 1 adedi "İyi", 5 adedi "Orta" ve 6 adedi ise "Zayıf" mera durumu olduğu; Uzun vd., (2016) Bartın ili, merkez ilçesine bağlı 15 köyün meralarının bitkiyle kaplı alan oranı ortalaması \% 93,57, meraların 1 adedi "Çok iyi", 1 adedi "İyi", 6 adedi "Orta" ve 7 adedi ise "Zayıf" mera durumu sınıfına girdiği; Babalık ve Fakır, (2017) Isparta ili Davraz Dağı Kozağacı Yaylası Kocapinar merasinda botanik kompozisyonunda, toplam buğdaygil oranı $\% 60,9$, baklagil oranı $\% 14,4$ diğer familyalara giren takson oranları ise $\% 24,7$ ve bitki ile kaplı alan oranı \%24,3 olduğu; Babalık ve Ercan, (2018) çalışma alanının bitkiyle kaplı alan değeri \% 51,2, mera alanının botanik kompozisyonunun sırasıyla buğdaygiller, baklagiller ve diğer familyalar oranı (\% 44, 23 ve 33) şeklinde oluştuğu; Sürmen ve Kara, (2018) ağırlı̆ga göre botanik kompozisyonda buğdaygillerin oranı 37,09, baklagillerin oranı $\% 4,24$ ve diğer familya bitkilerin oranı $\% 58,67$ bulduğu; Çınar vd., (2019) meralarda bitki ile kaplı alanda ortalama olarak buğdaygillerin oranı $\% 36,9$, baklagillerin oranı $\% 22,0$ ve diğer familya bitkilerin oranı $\% 41,1$, mera kalite derecelerinin 2,40-3,92 arasında değiştiği ve meraların durum sınıfının zayıf olduğu araştırıcılar tarafindan belirtilmiştir. Rize ilinde bitkisel çeşitliliğin ortaya konmasını amaçlayan çalışmaları (Çobanoğlu, 2012; Baykal ve Atamov, 2016; Baykal ve Atamov, 2017; Süzen, 2017; Baykal ve Atamov, 2018; Baykal vd., 2018 ve Baykal, 2019) yapılmış olsa da Ovit yaylasının botanik kompozisyon özelliğini bildiren bir çalışma yoktur. Bu çalışmada, Rize ilinin İkizdere ilçesine bağlı Ovit yaylasının merasında bulunan bitkilerin familya ve taksonları belirlenerek, mera vejetasyonunun toprağı kaplama ve botanik kompozisyon oranları tespit edilmesi ve meranın kalite derecesi ve durumu hakkında bilgi sahibi olunması amaçlanmıştır. $\mathrm{Bu}$ sayede meranın muhtemel iyileştirme esaslarını esasları ortaya koyarak ve ileride daha detaylı uygulamalar ile mera amenajmanı ve ıslah programlarına yön vermek amaçlanmıştır.

\section{MATERYAL VE METOT}

Araştırma Alanı: Bu araştırma 2019 yılında Rize ili İkizdere ilçesine bağlı deniz seviyesinden yaklaşı $2680 \mathrm{~m}$ yükseklikte $\left(40^{\circ} 37^{1} 31,0^{11} \mathrm{~N}, 40^{\circ} 46^{1} 55,5^{11} \mathrm{E}\right)$ ve ilçeye $90 \mathrm{~km}$ uzaklıkta bulunan Ovit yaylasının yaklaşık 20 da alanında yapılmıştır (Resim 1). Çalışsma sahasından çekilen bazı fotoğraflar Resim 2'de verilmiş̧ir.

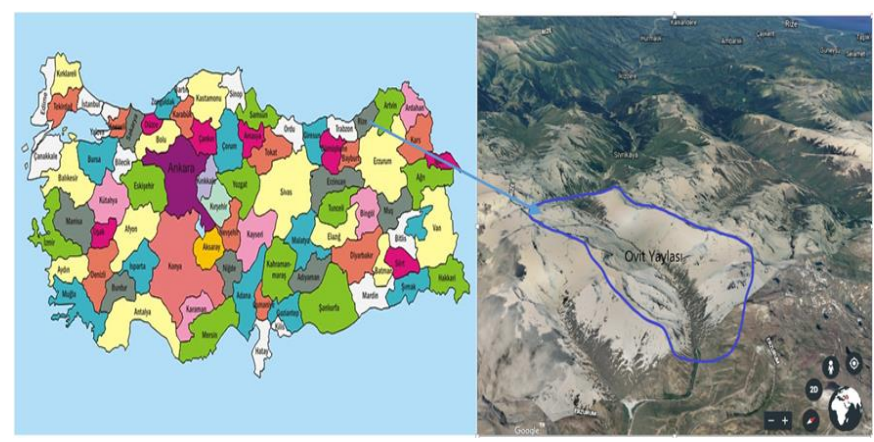

Resim 1: Çalışma alanının konumu. 


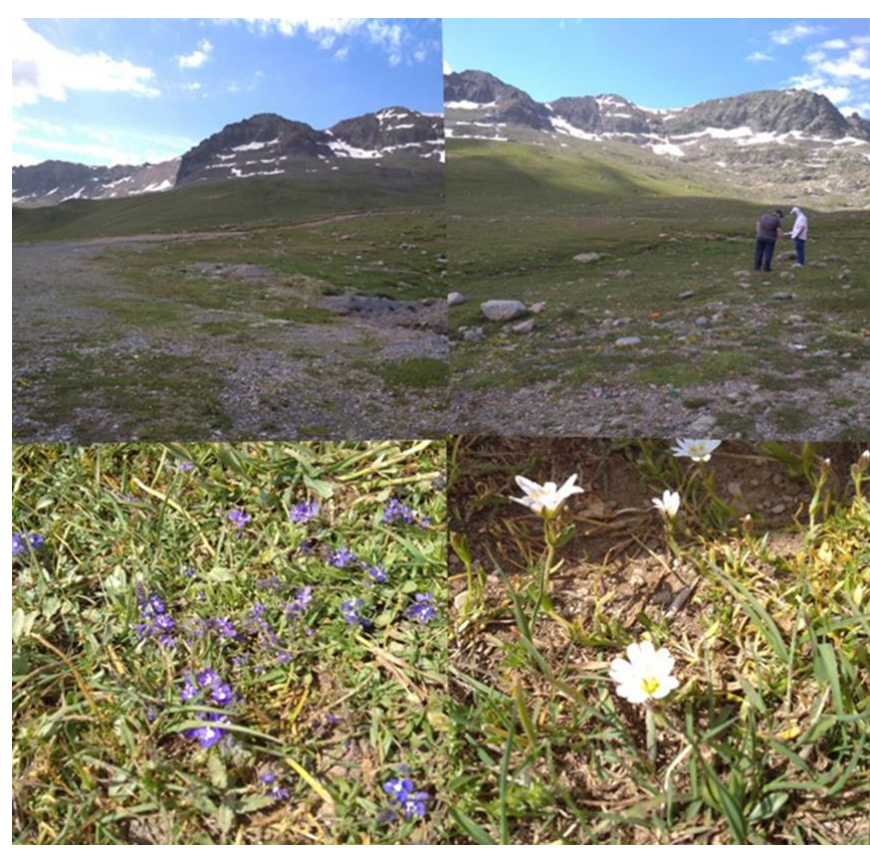

Resim 2: Çalışma alanından bazı görüntüler.

Metot: Ölçümler Haziran-Temmuz ayında vejetasyonu oluşturan bitkilerin vejetatif gelişimini tamamlayıp, generatif devre içinde bulundukları dönemde yani bitkilerin çiçeklenme devresinde yapılmıştır. Uzun yıllar sıcaklık ortalamas $14,3^{\circ} \mathrm{C}$, yağış miktarı $2296 \mathrm{~mm}$ ve nisbi nem $\% 80$ olarak belirlenmiştir (Anonim, 2019). Taksonların teşhisi Türkiye florası kullanılarak gerçekleştirilmiştir (Davis, 1965-1985; Davis vd., 1988; Güner vd., 2000). Teşhis edilen örnekler Türkiye Bitkileri Listesi (Damarlı Bitkiler) (Güner vd, 2012) kullanılarak kontrol edilmiştir. Çalışma alanının botanik kompozisyonunun belirlenmesinde Lup yöntemi kullanılmıştır. Lup çap $2 \mathrm{~cm}$, bir Lup hattı 20 m uzunlukta ve Luplar arası mesafe $20 \mathrm{~cm}$ olmak üzere bir Lup hattında toplamda 100 Lup hesaplanmıştır.

İstatistiksel Analiz: Botanik kompozisyonun belirlenmesinde Tosun, (1968)'un belirttiği esaslar dikkate alınarak her bir ana hat üzerinde 10 Lup hat olacak şekilde 5 ana hat ölçülmüştür. Lup ölçümlerinde bitkiye rastlanılan Lup alanlarının, toplam Lup alanına bölünmesiyle toprağı kaplama alanı belirlenmiştir (Gökkuş vd., 1993). Botanik kompozisyonda yer alan bitkilere Gökkuş vd., (1993) ve Bakoğlu (1999)'nun belirttikleri esaslar dahilinde ve Anonim (2008)'de bitkilerin yem olarak değerlendirilmesi durumuna göre -1 ile 10 arasında puanlar verilmiş, daha sonra botanik kompozisyondaki oranları ile çarpılarak, tüm taksonlara ait değerlerin toplanmasıyla mera kalite derecesine göre (Tablo 1) meranın durum sınıfı bulunmuştur. Ölçümlerin hesaplamasında kullanılan formüller aşağıda verilmiştir.

\%Botanik Kompozisyon= $($ Rastlanılan A taksonu sayıs1 / Toplam Bitki Sayıs1) x 100.

\%Toprağı Kaplama O.= (Bitkiye rastlanılan ölçüm alanı sayıs1 / Top. ölçüm alanı)x 100.

Mera Kalite Derecesi $=\sum$ (Taksonun Bot. Kom. \% oranı x Değer sayısı) /100.
Tablo 1: Mera Durumu Skalas1 (De Vries vd., 1951).

\begin{tabular}{ll}
\hline Kalite Derecesi & Mera Durumu \\
\hline $8.1-10$ & Çok iyi \\
\hline $6.1-8$ & İyi \\
\hline $4.1-6$ & Orta \\
\hline $2.1-4$ & Zayıf \\
\hline $0.0-2$ & Çok Zayıf \\
\hline
\end{tabular}

\section{BULGULAR}

Çalışmada tespit edilen takson listesi, familyası, toprağı kaplama ve botanik kompozisyon oranı ve mera derecesi Tablo 2'de, familyaların toprağ kaplama ve botanik kompozisyon oranları Şekil 1'de, familyalara göre mera dereceleri Şekil 2'de ve familyalara göre takson sayısı Șekil 3'de verilmiştir.

Tablo 2. Ovit yaylasının mera alanında bulunan bitkilerin familya, takson, değer sayısı, toprağı kaplama ve botanik kompozisyon oranı ve mera dereceleri.

\begin{tabular}{|c|c|c|c|c|c|c|}
\hline $\mathbf{N}$ & Takson adı & Türkçe & DS & TKO & BK & MD \\
\hline & $\begin{array}{l}\text { BUĞDAYGILLER } \\
\text { Poaceae }\end{array}$ & & & & & \\
\hline 1 & $\begin{array}{l}\text { Alopecurus gerardii (All.) } \\
\text { Vill. var. gerardii }\end{array}$ & Kösetilkikuyruğu & 3 & 0,70 & 1,21 & 0,036 \\
\hline 2 & Briza minör $\mathrm{L}$. & Küçükzembil & 1 & 0,50 & 0,72 & 0,007 \\
\hline 3 & $\begin{array}{l}\text { *Festuca woronowii Hack. } \\
\text { subsp. turcica Markgr., } \\
\text { Dannenb }\end{array}$ & Amasya yumağ & 2 & 11,20 & 17,66 & 0,353 \\
\hline 4 & Phleum alpinum $\mathrm{L}$. & Alp itkuyruğu & 4 & 1,10 & 1,82 & 0,073 \\
\hline 5 & Poa bulbosa $\mathrm{L}$. & Yumrulu salkım & 4 & 3,00 & 4,04 & 0,162 \\
\hline \multirow[t]{3}{*}{6} & Nardus stricta L. & Kilotu & 3 & 7,90 & 13,90 & 0,417 \\
\hline & & Toplam & & 24,40 & 39,35 & 1,048 \\
\hline & $\begin{array}{l}\text { BAKLAGILLER } \\
\text { Fabaceae }\end{array}$ & & & & & \\
\hline 1 & Astragalus fragrans Willd. & Mis geven & 3 & 2,30 & 3,20 & 0,096 \\
\hline 2 & Astragalus frickii Bunge & Artvingeveni & 3 & 0,80 & 0,93 & 0,028 \\
\hline 3 & $\begin{array}{l}\text { Securigera orientalis } \\
\text { (Mill.) Lassen subsp. }\end{array}$ & Ala körigen & 3 & 0,80 & 1,36 & 0,041 \\
\hline \multirow[t]{3}{*}{4} & $\begin{array}{l}\text { orientalis } \\
\text { Trifolium repens L. var. } \\
\text { repens }\end{array}$ & Ak üçgül & 8 & 0,60 & 1,12 & 0,090 \\
\hline & & Toplam & & 4,50 & 6,61 & 0,254 \\
\hline & DíĞER FAMİLYALAR & & & & & \\
\hline 1 & $\begin{array}{l}\text { Apiaceae } \\
\text { Chamaesciadium acaule } \\
\text { (M.Bieb.) Boiss. }\end{array}$ & Hamotu & 3 & 1,60 & 2,22 & 0,067 \\
\hline 2 & $\begin{array}{l}\text { Pimpinella rhodantha } \\
\text { Boiss. }\end{array}$ & Gülanason & 1 & 0,20 & 0,27 & 0,003 \\
\hline 3 & $\begin{array}{l}\text { Asteraceae } \\
\text { Anthemis cretica } \mathrm{L} .\end{array}$ & Kaf papatyası & 2 & 0,10 & 0,18 & 0,004 \\
\hline 4 & $\begin{array}{l}\text { *Doronicum balansae } \\
\text { Cavill. }\end{array}$ & Rize kaplanotu & 0 & 0,40 & 0,69 & 0,000 \\
\hline 5 & $\begin{array}{rr}\text { Pilosella } & \text { hoppeana } \\
\text { (Schult.) } & \text { F.W.Schultz \& }\end{array}$ & Toros tırnakotu & 0 & 0,30 & 0,74 & 0,000 \\
\hline & $\begin{array}{lr}\text { Sch.Bip.subsp. } & \text { cilicica } \\
\text { (Nägeli \& Peter) } & \text { P.D.Sell } \\
\text { \& C.West } & \end{array}$ & & & & & \\
\hline 6 & Taraxacum stevenii DC. & Gelingöbeği & 5 & 0,80 & 1,34 & 0,067 \\
\hline 7 & $\begin{array}{l}\text { Boraginaceae } \\
\text { Myosotis } \\
\text { F.W.Schmidt }\end{array}$ & Boncukotu & 0 & 2,40 & 3,95 & 0,000 \\
\hline 8 & $\begin{array}{l}\text { Brassicaceae } \\
\text { Cardamine impatiens L. } \\
\text { subsp. pectinata (Pall. ex } \\
\text { DC.) Stoj. \& Stef. }\end{array}$ & Taraklı kodimotu & 0 & 0,20 & 0,38 & 0,000 \\
\hline 9 & Draba hispida Willd. & Kıllı dolama & 0 & 0,70 & 1,14 & 0,000 \\
\hline 10 & $\begin{array}{l}\text { Caryophyllaceae } \\
\text { Cerastium purpurascens } \\
\text { Adams }\end{array}$ & Alaca boynuzotu & 3 & 1,30 & 1,94 & 0,058 \\
\hline 11 & $\begin{array}{l}\text { Minuartia verna }(\mathrm{L} .) \text { Hiern } \\
\text { subsp. verna }\end{array}$ & Yaz tıstis1 & 1 & 3,80 & 5,92 & 0,059 \\
\hline 12 & Silene odontopetala Fenzl & Kunduzotu & 1 & 0,20 & 0,28 & 0,003 \\
\hline 13 & $\begin{array}{l}\text { Crassulaceae } \\
\text { Sedum tenellum M.Bieb. }\end{array}$ & Narin damkoruğu & 0 & 0,30 & 0,51 & 0,000 \\
\hline 14 & $\begin{array}{l}\text { Cyperaceae } \\
\text { Carex atrata } \quad \text { L. } \quad \text { subsp. } \\
\text { atrata }\end{array}$ & Karasaparna & 1 & 0,70 & 1,05 & 0,011 \\
\hline 15 & $\begin{array}{l}\text { Carex nigra (L.) Reichard } \\
\text { subsp. dacica (Heuff.) Soó }\end{array}$ & Rumen ayakotu & 1 & 1,80 & 2,90 & 0,029 \\
\hline 16 & $\begin{array}{l}\text { Carex nigra (L.) Reichard } \\
\text { subsp. nigra }\end{array}$ & Kara ayakotu & 1 & 0,30 & 0,57 & 0,006 \\
\hline & Gentianaceae & & & & & \\
\hline 17 & Gentiana gelida M.Bieb. & Dağ gentiyanı & 0 & 0,40 & 0,62 & 0,000 \\
\hline 18 & Gentiana pyrenaica $\mathrm{L}$. & Pir gentiyan1 & 0 & 0,50 & 0,82 & 0,000 \\
\hline
\end{tabular}




\begin{tabular}{|c|c|c|c|c|c|c|}
\hline 19 & $\begin{array}{llr}\text { Geraniaceae } & \\
\text { *Geranium } & \text { ponticum } \\
\text { (P.H.Davis \& } & \text { J.Roberts) } \\
\text { Aedo } & & \\
\end{array}$ & Yayla ittr1 & 2 & 0,20 & 0,32 & 0,006 \\
\hline 20 & $\begin{array}{l}\text { Lamiaceae } \\
\text { Ajuga orientalis } \mathrm{L} \text {. }\end{array}$ & Dağmayasilı & 0 & 0,30 & 0,36 & 0,000 \\
\hline 21 & $\begin{array}{l}\text { Liliaceae } \\
\text { Fritillaria latifolia Willd. }\end{array}$ & Yaylalâlesi & 0 & 0,10 & 0,14 & 0,000 \\
\hline 22 & $\begin{array}{l}\text { Orchidaceae } \\
\text { Dactylorhiza } \\
\text { (Nevski) suxina } \\
\text { (Nevski) H. Baumann \& } \\
\text { Künkele }\end{array}$ & Laz salebi & 2 & 0,20 & 0,23 & 0,005 \\
\hline 23 & $\begin{array}{l}\text { Orobanchaceae } \\
\text { Pedicularis comosa } \text { L. var. } \\
\text { acmodonta (Boiss.) Boiss. }\end{array}$ & Hotozlu bitotu & -1 & 0,40 & 0,76 & $-0,008$ \\
\hline 24 & $\begin{array}{l}\text { Pedicularis nordmanniana } \\
\text { Bunge }\end{array}$ & Mevzetotu & -1 & 0,30 & 0,48 & $-0,005$ \\
\hline 25 & $\begin{array}{l}\text { Papaveraceae } \\
\text { Corydalis alpestris } \\
\text { C.A.Mey. }\end{array}$ & Gök kazgagası & 3 & 2,30 & 3,16 & 0,095 \\
\hline 26 & $\begin{array}{l}\text { Polygalaceae } \\
\text { Polygala alpestris Rchb. }\end{array}$ & Yayla sütotu & 1 & 1,00 & 1,72 & 0,017 \\
\hline $\begin{array}{l}27 \\
28 \\
\end{array}$ & $\begin{array}{l}\text { Primulaceae } \\
\text { Primula algida Adams } \\
\text { Primula auriculata Lam. }\end{array}$ & $\begin{array}{l}\text { Dağtutyası } \\
\text { Felçotu }\end{array}$ & $\begin{array}{l}6 \\
3 \\
\end{array}$ & $\begin{array}{l}1,10 \\
0,70 \\
\end{array}$ & $\begin{array}{l}1,32 \\
0,98 \\
\end{array}$ & $\begin{array}{l}0,079 \\
0,029 \\
\end{array}$ \\
\hline 29 & $\begin{array}{l}\text { Ranunculaceae } \\
\text { Ranunculus buhsei Boiss. }\end{array}$ & Çingotu & -1 & 1,50 & 2,24 & $-0,022$ \\
\hline 30 & $\begin{array}{l}\text { Rosaceae } \\
\text { Sibbaldia parviflora Willd. } \\
\text { var. parviflora }\end{array}$ & Findıkotu & 1 & 8,00 & 12,80 & 0,128 \\
\hline 32 & Alchemilla retinervis Buser & Damarlı keltat & 0 & 0,50 & 0,94 & 0,000 \\
\hline 33 & $\begin{array}{l}\text { Rubiaceae } \\
\text { Cruciata taurica (Pall. ex } \\
\text { Willd.) Ehrend. }\end{array}$ & Kırım güzeli & 0 & 0,80 & 1,34 & 0,000 \\
\hline & Violaceae & & & & & \\
\hline 34 & Viola altaica Ker.-Gawl. & Altaymenekşesi & 3 & 0,20 & 0,42 & 0,013 \\
\hline \multirow[t]{3}{*}{35} & Viola odorata $\mathrm{L}$. & Kokulu menekșe & 3 & 0,60 & 0,88 & 0,026 \\
\hline & & Toplam & & $\mathbf{3 4 , 5 0}$ & 54,04 & 0,673 \\
\hline & GENEL TOPLAM & & & 63,40 & 100,00 & 1,976 \\
\hline
\end{tabular}

Tablo 2'ye bakıldığında çalışılan meranın toprağı kaplama oranı \%63,40 olarak bulunmuştur. Mera da buğdaygiller $\% 24,40$, baklagiller $\% 4,50$ ve diğer familya bitkileri $\% 34,50$ oranında toprağı kaplamıştır. Vejetasyon etüdünde toplam 22 familya da 45 farklı takson tespit edilmiş ve bunlardan 6 tanesi buğdaygil (\%39,35), 4 tanesi baklagil $(\% 6,61)$ ve 35 tanesi de $(\% 54,04)$ diğer familyaya ait bitkilerden oluşmuştur. Mera kalite derecesi 1,976 ile meranın durumunun çok zayıf olduğu belirlenmiştir. Çalışılan meranın botanik kompozisyonunda bulunan bitkilerden buğdaygillerden Amasya yumağı (Festuca woronowii Hack. subsp. turcica Markgr., Dannenb) (\%17,66), K1lotu (Nardus stricta L.) $(\% 13,90)$ ve Yumrulu salkım (Poa bulbosa L.) (\%4,04); baklagillerden Mis geven (Astragalus fragrans Willd.) (\%3,20), Ala körigen (Securigera orientalis (Mill.) Lassen subsp. orientalis) $(\% 1,36)$ ve Ak üçgül (Trifolium repens $\mathrm{L}$. var. repens) $(\% 1,12)$; diğer familyalardan Findıkotu (Sibbaldia parviflora Willd. var. parviflora) $(\% 12,80)$, Yaz tistıs1 (Minuartia verna (L.) Hiern subsp. verna) $(\% 5,92)$ ve Boncukotu (Myosotis alpestris F.W.Schmidt) $(\% 3,95)$ ilk üç sırayı oluşturmaktadır. Ayrıca çalışma alanının mera bitkilerinden Amasya yumağı (F. woronowii Hack. subsp. turcica Markgr., Dannenb), Rize kaplanotu (Doronicum balansae Cavill.) ve Yayla itırı (Geranium ponticum (P.H.Davis \& J.Roberts) Aedo) bitkileri endemiktir.

Araştırmadan elde ettiğimiz sonuçlar ile diğer araştırıcıların (Babalık ve Sarıkaya, 2015; Gür ve Altın, 2015; Bilgin ve Özalp, 2016; İspirli vd., 2016; Uzun vd., 2016; Babalık ve Fakır, 2017; Babalık ve Ercan, 2018;
Sürmen ve Kara, 2018; Çınar vd., 2019) bulguları arasında benzerlik ve farklılıklar bulunmaktadır. Farklılıkların ortaya çıkmasına meraların farklı vejetasyon koşulları, farklı ekolojiler ve uygulamalardan kaynaklanmış olabilir.

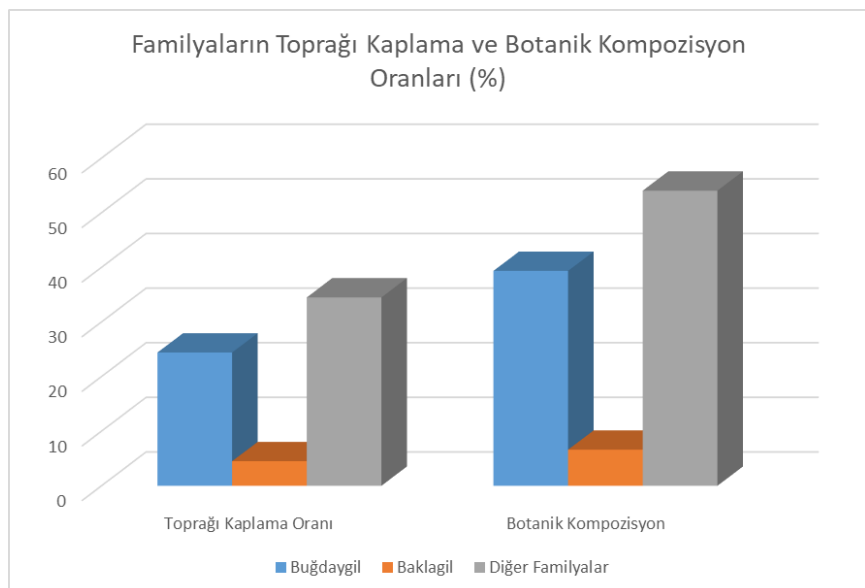

Şekil 1: Familyaların Toprağı Kaplama ve Botanik Kompozisyon Oranları (\%).

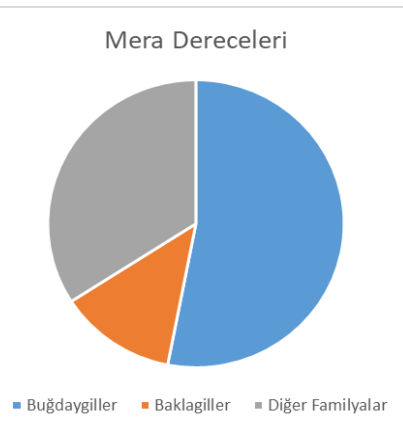

Şekil 2: Familyalara Göre Mera Dereceleri.

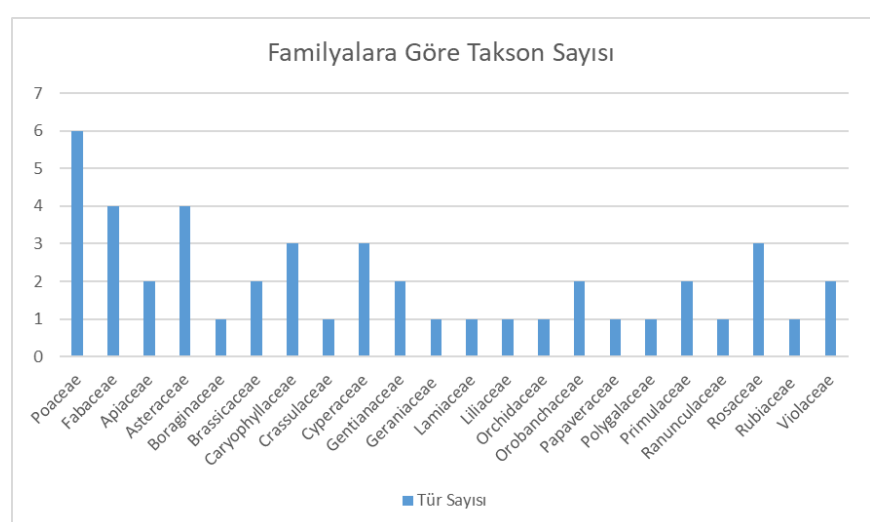

Şekil 3: Familyalara Göre Takson Sayısı.

\section{SONUÇ}

Sonuç olarak yapilan çalışmada 6 buğdaygil, 4 baklagil ve 35 tane de diğer familyadan bitkiler olmak üzere toplamda 45 takson tespit edilmiş̧ir. Mera bitkilerinin toprağ 1 kaplama oranı $\% 63,40$, toprağı kaplama alanına göre botanik 
kompozisyonları buğdaygil \%39,35, baklagil \%6,61 ve diğer familya bitkileri \%54,04 oranında bulunmuştur. Merada en yaygın bulunan ilk üç takson sırasıyla; $F$. woronowii Hack. subsp. turcica Markgr., Dannenb (\%17,66), N. stricta L. $(\% 13,90)$ ve $S$. parviflora Willd. var. parviflora $(\% 12,80)$ olmuştur. \%1,976 mera derecesi ile meranın durumu çok zayıf olarak belirlenmiştir. Çalışma alanında tespit edilen taksonlardan Amasya yumağı (F. woronowii Hack. subsp. turcica Markgr., Dannenb)(\%17,66), Rize kaplanotu (D. balansae Cavill.) $(\% 0,69)$ ve Yayla itır1 (G. ponticum (P.H.Davis \& J.Roberts) Aedo)(\%0,32) taksonlar1 endemiktir. Araştırma sonuçlarına göre incelenen mera ve benzer ekolojik koşullardaki meralarda başta aşırı, düzensiz ve zamansız otlatmadan kaçınılarak otlatmanın kontrol altına alınması ve yem değeri yüksek mera bitkilerini üstten tohumlama suretiyle diğer ıslah yöntemlerinin kombineli bir şekilde uygulanmasına yönelik yeni araştırmaların yapılması sonucuna varılmıştır.

\section{KAYNAKLAR}

Anonim. (2008). Türkiye’nin çayır ve mera bitkileri. Tarım ve Köyişleri Bakanlığı Tarımsal Üretim ve Geliştirme Genel Müdürlüğü Yayınları, 468 s.

Anonim. (2018). Rize mera alanı. (Erişim: 24.03.2019). https://rize.tarim.gov.tr/Menu/13/Ekonomi.

Anonim. (2019). T.C. Başbakanlık Devlet Meteoroloji İşleri Genel Müdürlüğü, Rize İl Müdürlüğü Kayıtları.

Aydın, İ. \& Uzun, F. (2002). Çayır-mera amenajmanı ve ıslahı. Ondokuz Mayıs Üniversitesi Ziraat Fakültesi Ders Kitab1, Samsun.

Babalık, A.A. \& Ercan, A. (2018). Eskişehir ili Karaören köyü merasının vejetasyon özelliklerinin belirlenmesi. Türkiye Ormancllık Dergisi, 19(3), 246-251.

Babalık, A.A. \& Fakır, H. (2017). Korunan ve otlatılan mera alanlarında vejetasyon özelliklerinin karşılaştırılması: Kocapınar Merası örneği. Türkiye Ormancılık Dergisi, 18(3), 207-211.

Babalık, A.A. \& Sarıkaya, H. (2015). Isparta ili Zengi merasında ot verimi ve botanik kompozisyonun tespiti üzerine bir araştırma. Türkiye Ormancılık Dergisi, 16(2), 96-101.

Bakoğlu, A. (1999). Otlatılan ve korunan iki farklı mera kesiminin bazı toprak ve bitki örtüsü özelliklerinin karşılaştırılması. Doktora Tezi, Atatürk Üniv. Fen Bil. Ens. Erzurum, Türkiye, 128s.

Baykal, H. \& Atamov, V. (2016). Floristic diversity in Bashemsin Valley of Kackar Mountains National Park of Rize, Turkey. Pakistan Journal of Botany, 48(5), 1871-1876.

Baykal, H. \& Atamov, V. (2017). Ethnobotanical documentationof plants of Başhemşin Valley,
Kaçkar Mountains National Park, Rize, Turkey. Bangladesh Journal of Botany, 46(2),767-773.

Baykal, H. \& Atamov, V. (2018). Isırlık Doğa Parkı ve çevresinin florası, Ot Sistematik Botanik, 25(2), 151170.

Baykal, H., Atamov, V. \& Yüksek, T. (2018). Flora of Tunca Valley Natural Park and environs (ArdeşenRize/Turkey). Biological Diversity and Conservation, 11, 6-24.

Baykal, H. (2019). Flora of Akyamaç Waterfall Natural Park and environs (Rize/Turkey). Biological Diversity and Conservation, 12, 128-137. Doi: 10.5505/biodicon.2019.98608.

Bilgin, F. \& Özalp, M. (2016). Yükselti değişimlerinin orman üstü meraların vejetasyon yapısı ve toprak özellikleri üzerine etkilerinin irdelenmesi. Artvin Çoruh Üniversitesi Orman Fakültesi Dergisi, 17(2), 135-147.

Carlier, L., De Vliegher, D., Van Cleemput, O. \& Boeckx, P. (2005). Importance and functions of European grasslands. Communications in Agricultural and Applied Biological Sciences, 70, 5-15.

Çınar, S., Hatipoğlu, R., Avcı, M., Yücel, C. \& İnal, İ. (2019). Adana ili Tufanbeyli ilçesi meralarının vejetasyon yapısı üzerine bir araştırma. Kahramanmaraş Sütçü İmam Üniversitesi Tarım ve Doğa Dergisi, 22(1), 143-152, Doi: 10.18016/ksutarimdoga.vi.448421.

Çobanoğlu, M. (2012). Güneysu-Çağrankaya arası bölgenin flora ve vejetasyonu. Yüksek Lisans Tezi, R Recep Tayyip Erdoğan Üniversitesi Fen Bilimleri Enstitüsü. Rize, Türkiye, 153s.

Davis, P.H. (1965-1985). Flora of Turkey and The East Aegean Islands, Vol. 1-9, Edinburgh University Press, Edinburgh.

Davis, P.H., Mill, R.R. \& Tan, K. (1988). Flora of Turkey and The East Aegean Islands, Vol. 10, Edinburgh University Press, Edinburgh.

De Vries, D.M., De Boer, T.A. \& Dirver, J.P.P. (1951). Evalation of grassland by botanical research in the Netherlands. In Proc. United National Sci. Conf. on the Conservation and Utilization of Resources, 6, 522-524.

Gökkuş, A., Koç, A. \& Çomaklı, B. (1993). Çayır-mera uygulama kılavuzu. A.Ü. Ziraat Fakültesi Yayınları No:142, A.Ü. Ziraat Fakültesi Ofset Tesisi, Erzurum.

Gökkuş, A. (1994). Türkiye'nin kaba yem üretiminde çayırmera ve yem bitkilerinin yeri ve önemi. Atatürk Üniversitesi Ziraat Fakültesi Dergisi, 25, 250-261.

Güner, A., Akyıldırım, B., Alkayış, M. F. Çıngay B., Kanoğlu, S.S., Özkan, A.M., Öztekin, M. \& Tuğ, G.N. (2012). Türkçe bitki adları. Şu eserde: Güner, A., aslan, S. Ekim, T. Vural, M. \& Babaç, M.T. 
(edlr.). Türkiye Bitkileri Listesi (Damarlı Bitkiler). Nezahat Gökyiğit Botanik Bahçesi Yayınları Flora Dizisi 1 İstanbul.

Güner, A., Özhatay, N., Ekim, T. \& Başer, K.H.C. (2000). Flora of Turkey. Vol. 11. Edinburgh University Press, Edinburgh.

Gür, M. \& Altın, M. (2015). Trakya yöresinde farklı kullanım geçmişine sahip meraların florastik kompozisyonlarının bazı özellikleri. Anadolu Tarım Bilimleri Dergisi, 30, 60-67. Doi: 10.7161/anajas.2015.30.1.60-67.

İspirli, K., Alay, F., Uzun, F. \& Çankaya, N. (2016). Doğal meralardaki vejetasyon örtüsü ve yapısı üzerine otlatma ve topografyanın etkisi. Türkiye Tarımsal Araştırmalar Dergisi, 3(1), 14-22.

Okatan, A. \& Yüksek, T. (1997). Aşırı otlatılan mera parsellerinde Adi korunga (Onobrychis viciifolia Scop.)'nın yetiştirilmesi ve verim potansiyeli üzerine araştırmalar. Türkiye 2. Tarla Bitkileri Kongresi, Ondokuz Mayıs Üniversitesi Ziraat Fakültesi, Samsun, s.492-498.

Sürmen, M. \& Kara, E. (2018). Aydın ili ekolojik koşullarında farklı eğimlerdeki mera vejetasyonlarının verim ve kalite özellikleri. Derim, 35, (1), 67-72, Doi: 10.16882/derim.2018.343428.

Süzen, A. (2017). Ambarlık Yaylası (Çamlıhemşin/Rize)'nın florasl ve vejetasyonu. Recep Tayyip Erdoğan Üniversitesi Fen Bilimleri Enstitüsü, Rize, Türkiye, 172 s.
Tosun, F. (1968). Doğu Anadolu kıraç meralarının ıslahında uygulanabilecek teknik metodların tesbiti üzerine bir araştırma. Zirai Araştırma Enstitüsü Araştırma Bülteni No: 29, Ankara.

TÜİK. (2019). Bitkisel üretim istatistikleri. (Erişim: 30.07.2019). http://www.tuik.gov.tr

Uzun, F., Alay, F. \& İspirli, K. (2016). Bartın ili meralarının bazı özellikleri. Türkiye Tarımsal Araştırmalar Dergisi, 3(2), 174-183.

Yavuz, T. \& Sürmen, M. (2016). Vegetation features of alpine and subalpine rangelands in Eastern Black Sea region. Scientific Papers Series A Agronomy, 54, 474-477.

\section{*Corresponding author's:}

Muhammed İkbal ÇATAL

Recep Tayyip Erdoğan Üniversitesi, Ziraat ve Doğa Bilimleri Fakültesi, Tarla Bitkileri Bölümü, Pazar/Rize/Türkiye.

\E-mail : muhammed.catal@erdogan.edu.tr

ORCID : https://orcid.org/0000-0002-4888-770X

GSM : +90(539) 3733592

Telefon : $+90(464) 6127317$

Faks : : +90 (464) 6127316 